RESEARCH ARTICLE

\title{
Effect of Stem Diameter, Moisture Content and Cutting Speed on Cutting Force for Groundnut Harvesting.
}

\author{
Preethi $\mathbf{R}^{\mathbf{1}^{*}}$, Saravanakumar $\mathbf{M}^{\mathbf{1}}$, Kamaraj $\mathbf{P}^{1}$ and Vallal Kannan $\mathbf{S}^{2}$ \\ ${ }^{1}$ Department of Farm Machinery and Power Engineering, Agricultural Engineering College and Research Institute, \\ Kumulur, Trichy- 621 712. Tamil Nadu Agricultural University. \\ ${ }^{2}$ Department of Agronomy Agricultural College and Research Institute, Madurai -625 104.Tamil Nadu Agricultural University.
}

\begin{abstract}
To design,and develop harvesting machines, the most important optimized parameter is the cutting force.The study was conducted to investigate the effect of stem diameter, moisture content, and cutting speed on the cutting force required for cutting groundnut stalks. The cutting force was measured using the reciprocating cutter bar test rig. Experiments were carried out at three levels of moisture content (40 - 47, 47 - 53, and 53 - $60 \%$ ) (wet basis), three levels of crop stem diameter (15-17, 17 - 19, and 19- 21 $\mathrm{mm}$ ) and three levels of cutter bar speed (0.80 - 0.90, $0.90-1.00$ and $\left.1.00-1.10 \mathrm{~ms}^{-1}\right)$. The cutting force required for cutting groundnut crop stem was calculated for all the treatments. It was observed that increase in stem diameter, the cutting force increased by $19.83 \%$ and increase in moisture content and cutter bar speed,the cutting force decreased by 37.57 $\%$, and $34.11 \%$, respectively. The required cutting force $(100-120 \mathrm{~N})$ and energy (1.5 - 2.0J) was minimum at the cutter bar speed of $1.00-1.10 \mathrm{~ms}^{-1}$ for 53 - $60 \%$ moisture content, 15 - $17 \mathrm{~mm}$ stem diameter and they were maximum at cutter bar speed of $0.80-0.90 \mathrm{~ms}^{-1}$ (140- $160 \mathrm{~N}$ and $2.5-3.0$ J)for 40 - $47 \%$ moisture content, 19 - $21 \mathrm{~mm}$ stem diameter. The results showed that the cutting force requirement was increased with an increase in stem diameter and decreased with an increase in moisture content and cutting speed.
\end{abstract}

Keywords: Groundnut; Cutting energy; Crop parameters; Stem diameter; Moisture content.

\section{INTRODUCTION}

The peanut, also called the groundnut (Arachis hypogaea) is a legume crop. It is said to be an oilseed crop, due to its high oil content. It gives vegetable protein and edible oilintropical and semi-arid tropical areas.It plays an important role both as an oil or food crop and is also grown as an important forage crop. Among the oilseed crops, it is the sixth most important oilseed crop globally. In India, it is cultivated under rain-fed conditions and irrigated lands. It has two crop cycles harvested in March \& October, so it is available throughout the year in India. Gujarat is the largest producer in India, followed by Tamil Nadu, Andhra Pradesh, Karnataka, and Maharashtra. Among the states in India, Tamil Nadu ranked first with 1.26 lakh ha in area coverage followed by Telangana Odisha and Karnataka 1.07, 0.91,and 0.72 lakh ha, respectively Anonymous (2019). In 2015-16 around Tamil $\mathrm{Nadu}$, the groundnutarea and production were 3.2 lakh hectares and 4 lakh tonnes, respectively. The major groundnut- producing districts in Tamil
Nadu are Thiruvannamalai, Villupuram, Vellore, Namakkal, Salem, Erode and Cuddalore(Thulasiram et al.,2018).It is grown, mainly for its edible quality. The physical properties of the plant stem and the cutting resistance play a vital role to in understanding the force required in harvesting operations.

In safflower stalk, the bottom region of the stalk with the moisture content of $37.16 \%$, registered the maximum shear energy of $938.33 \mathrm{~mJ}$ and shear stress of $11.04 \mathrm{MPa}$. An increase in the shear stress and shear energy is due to an increase in the moisture content of the safflower stalk (Shahbzi and Galedar 2012). The effect of stem diameter, moisture contenton cutting energyfor cassava stem was studied.At $33.29 \mathrm{~mm}$ stem diameter, the cutting energy was maximum (34.84 J) and at $25.22 \mathrm{~mm}$ stem diameter, the cutting energy was minimum $(28.81 \mathrm{~J})$. As the stem diameter increased from 25.22 to $33.29 \mathrm{~mm}$, the cutting energy increased by $17.31 \%$ (Prasanthkumar and Saravanakumar 2020). The effect of Bengal gram cropand machine parameters on cutting energy was investigated.A 
double cutter bar test rig for measuring the cutting force to cut Bengal gram crop and the minimum cutting energy required to cut the Bengal gram crop was $0.67 \mathrm{Nm}$ (Ramachandran and Asokan 2020). A pendulum-type impact test rig was used to investigate the effect of cutting velocity, blade type, and stalk cross-sectional area on cutting energy, specific energy, and cutting force for chickpea stalks. The maximum cutting velocity and cutting force at stalk diameter were $1.50 \mathrm{~ms}^{-1}$ and $702.80 \mathrm{~N}$ at $24 \mathrm{~mm}$ (Sushilendra et al.,2016). The investigation on the effect of moisture content, bevel angle and cutting speed on shearing energy for three wheat varieties. They reported that a decrease in shearing energy would increase the shearing speed and with decreasing moisture content and bevel angle (Hoseinzadeh et al.,2009).

\section{Need and importance of groundnut vine cutting machine}

During, harvesting of the entire groundnut crop, the pants were damaged. After harvesting of groundnut crop, the stripping method was done to remove the groundnut pods from the plants. While stripping, the wastage of groundnut vines occurred. To avoid these damages, the groundnut vine cutting machine was developed. The importance of this machine was there would be a minimum force required for digging the groundnut crop. Removing pods from the ground nut crop, threshing and picking operations could be done easily.

\section{MATERIAL AND METHODS}

The parameters pertinent to influencethe cutting of groundnut crop stem were identified as stem diameter, moisture content and linear speed of the cutter bar.

\section{Crop parameter}

\section{a. Stem Diameter}

Randomly ten samples of groundnut plants were taken at the harvesting stage and diameter was measured from the ground level at 5 to $7 \mathrm{~cm}$ height. Each groundnut plant consisted of number of branches varying from 5 to 6 branches. The whole plant (a bunch of stems) was taken for the experiment. The diameter of the stem was measured using the Vernier caliper and the readings were noted in $\mathrm{mm}$.

\section{b. Moisture content}

Immediately after cutting the stem, 15 to 20 numbers of small pieces were taken as samples for measuring the moisture content. The moisture content was measured by weighing its initial weight in an electronic weighing balance $\left(w_{s}\right)$ with an accuracy of $1 \mathrm{~g}$. A sample was placed on a crucible and kept inside the oven for 24 hours at $105^{\circ} \mathrm{C}$ to eliminate the moisture (Gravimetric method). (Talpur et al.,2011). The dried weight of the sample was measured and noted as $\mathrm{w}_{\mathrm{d}}$. The moisture content of the sample was worked out on a wet basis using the formula,

Moisture content (w.b) $=\frac{\text { Ws- Wd }}{\text { Ws }} \times 100$ per cent

Where,

$\mathrm{w}_{\mathrm{s}}=$ weight of groundnut stem before drying, $\mathrm{g}$

$\mathrm{W}_{\mathrm{d}}=$ weight of the dried groundnut stem, $\mathrm{g}$

\section{Machine Parameter}

\section{a. Linear Speed of Cutter Bar}

The linear speed of the cutter bar was given by the following equation (Celik, 2006).

Knife speed, $\quad V_{k}=\frac{\mathrm{sxn}}{30}$

Where,

$\mathrm{V}_{\mathrm{k}}=$ knife speed, $\mathrm{ms}^{-1}$

$\mathrm{s}=$ length of stroke, $\mathrm{m}$

$\mathrm{n}=$ crank speed, rpm

\section{Evaluation Parameter}

\section{a. Cutting force}

The force required for cutting the ground nut crop stem was measured using the load cell expressed in kilogram. The measured cutting force values were recorded.

\section{b. Cutting energy}

The cutting energy could be determined using the formula.

Cutting energy, $\quad E_{c}=F_{c} \times D$

Where,

$\mathrm{E}_{\mathrm{c}}=$ cutting energy, $\mathrm{J}$

$\mathrm{F}_{\mathrm{c}}=$ cutting force, $\mathrm{N}$

$\mathrm{D}=$ diameter, $\mathrm{mm}$

\section{Reciprocating cutter bar test rig}

The cutting force was measured using the test rig, fabricated for measuring the cutting energy. The cutter bar test rig consisted of mainframe, cutter bar assembly, load cell, load indicator, load measuring set up, analog to digital converter, variable speed drive, power transmission assembly, signal conditioning and the amplifying unit, digital load measuring set up and power supply. (Figure.1) Nisha and Saravana kumar (2019 b) 


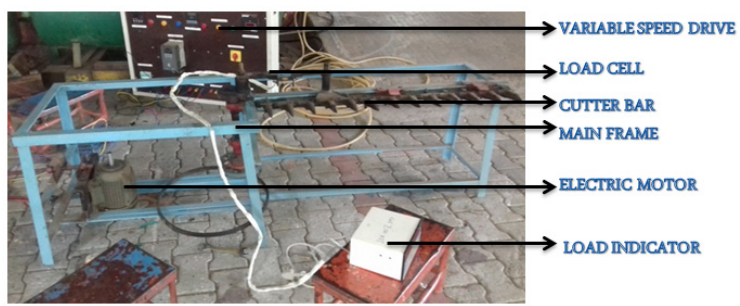

Figure 1. Reciprocating Cutter Bar Test Rig

\section{Mainframe}

The mainframe was made of mild steel ' $L$ ' angle size of $32 \times 32 \times 6 \mathrm{~mm}$. The total length and height of themain frame were1790 $\times 500$ $\mathrm{mm}$, respectively. The main frame consists of cutter bar assembly, connecting rod, electric motor (1 hp), power transmission system and digital load measuring set up.
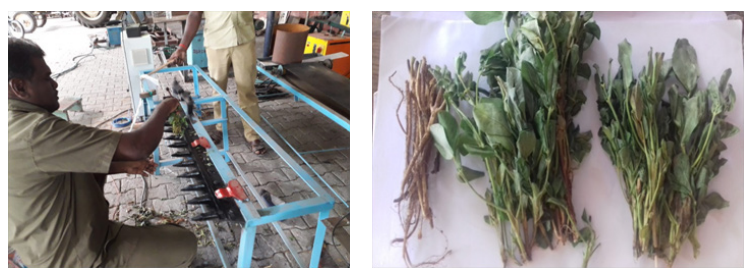

\section{Cutter bar Assembly}

The cutter bar assembly comprisesthe cutter bar, knife guard and knife clip.The size of the cutting knives was $76.2 \mathrm{~mm}$. The cutter bar was formed by riveting the fourteen number of cutting knives on mild steel flat. The total length of the cutter bar was $1015 \mathrm{~mm}$ was mounted on the main frame by using an 'L' angle of size $32 \times 32 \times 6 \mathrm{~mm}$ and at the height of $500 \mathrm{~mm}$ from the ground level. Using bolt and nuts, the eleven numbers of knife guards were mounted on mild steel 'L' angle of size $32 \times$ $32 \times 6 \mathrm{~mm}$ and length $1015 \mathrm{~mm}$ at a distance of $76.2 \mathrm{~mm}$. Two knife clips were mounted on main the frame foreffective cutting action.

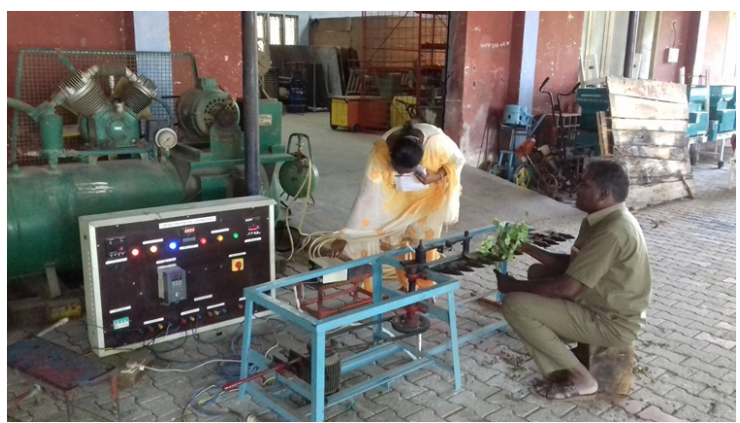

Figure 3. Readings were taken during Experiment.

\section{Load Cell}

A load cell measures the load or force encountered during cutting the groundnut stem and converts pressure into electrical signals and vice versa. The cutting force was measured by using an S-type load cell.

\section{Load Indicator}

A load indicator was used to indicate the cutting force. It displays the measured value in four digits. Itconsists of three parts namely analog to digital converter, signal conditioning with amplifying unit and power supply.

Table.1. Analysis of variance for the effect of crop diameter,moisture content and cutter bar speed on cutting force.

\begin{tabular}{lccccc}
\hline $\begin{array}{c}\text { ANOVA } \\
\text { RESULTS }\end{array}$ & df & Sum & $\begin{array}{c}\text { Sq } \\
\text { Mean }\end{array}$ & $\begin{array}{c}\text { Sq F } \\
\text { Value }\end{array}$ & $\operatorname{Pr}(>\mathbf{F})$ \\
\hline Diameter & 1 & 1070.3 & 1070.3 & 509.7 & $0.01 * *$ \\
Residuals & 1 & 2.1 & 2.1 & & \\
& & & & &
\end{tabular}

Moisture Content $11056.51056 .566 .61 \quad 0.0776 *$

$\begin{array}{llll}\text { Residuals } & 1 & 15.9 & 15.9\end{array}$

Cutter bar Speed $11067.8 \quad 1067.8235 .2 \quad 0.0415$ **

$\begin{array}{llll}\text { Residuals } & 1 & 4.5 & 4.5\end{array}$

\section{Analog to Digital Converter}

The output from the amplifier was noted in terms of analog DC voltage. This analog output was converted into digital output using an Analog to Digital converter.

\section{Variable Speed Drive}

The variable speed drive is an electronic device used to vary the speed, torque and direction of the induction motor. It is connected to the three-phase induction motor through electric wires.

\section{Power Transmission Assembly}

The cutter bar assembly was operated by taking the mechanical power from the electric motor. To operate the test rig, a one hp three-phase induction electric motor was selected as the prime mover.

\section{Signal Conditioning and Amplifying Unit}

The signal conditioner also protects the input signal given to the differential amplifier.

\section{Digital Load Measuring Set Up}

Digital load measuring setup consists of a load cell and a load indicator.

\section{Power Supply}

A power supply of $\pm 12 \vee 500 \mathrm{~mA}$ was used to operate the digital integrated circuitry (signal conditioning and amplifying unit) and the Analog to Digital converter(load indicator without error), respectively. 
The sample was placed between reciprocating cutting knife for cutting groundnut stems of diameter varying from 15 to $21 \mathrm{~mm}$ (Figure.2).The load cell measured the force required and noted from the load indicator in kilogram(Figure.3). The force required at different stem diameter and moisture content was worked out for its average and it is discussed below.

\section{Operational Parameters}

Experiments were carried out at three levels of groundnut stem diameter (15-17, 17 - 19, and 19$21 \mathrm{~mm}$ ), three levels of moisture content (40 - 47, $47-53$, and $53-60 \%$ ) (wet basis), and three levels of cutter bar speed $(0.80-0.90,0.90-1.00$ and $\left.1.00-1.10 \mathrm{~ms}^{-1}\right)$.

\section{RESULTS AND DISCUSSION}

This study measured the cutting force required to cut groundnut stems at three different levels of moisture content and three levels of stem diameters with a reciprocating cutter bar test rig.

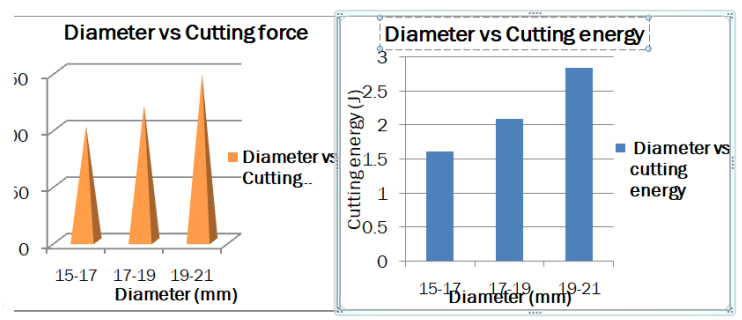

Figure 4. Effect of groundnut stem diameter on cutting forceand cutting energy

\section{Effect of groundnut stem diameter on cutting force and cutting energy}

The relation between the stem diameter and required cutting force and cutting energy is shown in Figure.4. At a stem diameter of $19-21 \mathrm{~mm}$, the maximum required cutting force of $140-160 \mathrm{~N}$ and cutting energy of 2.5 - $3.0 \mathrm{~J}$ were measured. At 15 - $17 \mathrm{~mm}$ lower stem diameter, the minimum required cutting force of $100-120 \mathrm{~N}$ and cutting energy of $1.5-2.0 \mathrm{~J}$ was measured. Therefore, when the stem diameter increased from 15 to $21 \mathrm{~mm}$, the required cutting force and cutting energy also increased.A similar trend was observed by Nisha and Saravanakumar (2019 a).They studied the effect of finger millet crop parameters (moisture content, stem diameter and cutter bar speed) on cutting force and energy. The experiment was conductedat three levels of moisture content, stem diameter and cutter bar speed of 62 to 63,70 to 71,77 to $80 \%$, 6,9 and $12 \mathrm{~mm}$ and $0.5,1.0,1.5$ and $2.0 \mathrm{~m} \mathrm{~s}^{-1}$, respectively. The results show that an increase in diameter increased the cutting force and energy.

\section{Effect of moisture content on cutting force and cutting energy}

The relation between the moisture content (w.b) and cutting force and cutting energy is shown in (Figure. 5). At 53 - $60 \%$ moisture content, the minimum required cutting force of $100-120 \mathrm{~N}$ and cutting energy of $1.5-2.0 \mathrm{~J}$ were recorded. At 40 - $47 \%$ moisture content, of the maximum required cutting force of $140-160 \mathrm{~N}$ and cutting energy of 2.5 - $3.0 \mathrm{~J}$ were recorded. Therefore, the required cutting force and cutting energy decreased when the moisture content increased.A similar trend was observed by Azadbakht et al. (2014). They investigated cutting energy for corn stalks and reported that the maximum cutting energy i.e. 3.22 $\mathrm{kJ}$ at $63 \%$ moisture content and $5 \mathrm{~cm}$ cutting height. The minimum cutting energy of $1.63 \mathrm{~kJ}$ at 83.25 $\%$ moisture content and $15 \mathrm{~cm}$ cutting height. The study revealed that the cutting energy was inversely proportional to the moisture content.

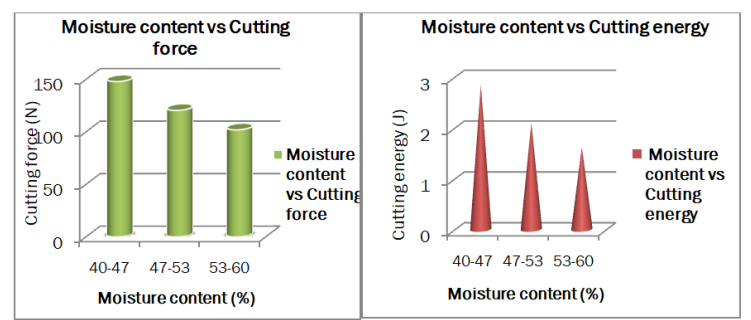

Figure 5. Effect of moisture content on cutting force and cutting energy

\section{Effect of cutting speed on cutting force and cutting energy}

The relation between the cutting speed cutting force and cutting energy is shown in (Figure. 6). The maximum required cutting force and cutting energy of $140-160 \mathrm{~N}$ and $2.5-3.0 \mathrm{~J}$, respectively was observed at $0.80-0.90 \mathrm{~ms}^{-1}$. The minimum required cutting force and cutting energy of 101.98 $\mathrm{N}$ and $1.5-2.0 \mathrm{~J}$, respectively was observed at1.00 - $1.10 \mathrm{~ms}^{-1}$. Therefore,the required cutting force and cutting energy decreased when the cutting speed increased.A similar trend was observed by Allameh and Alizade(2016). They reported the effect of specific cutting energy on different rice stem cultivars and blade parameters. The experiments were carried out at four levels of blade bevel angle $25,30,35$ and 40 degrees, at three levels of cutting angle and blade speed of 25,30 , and 35 degrees and 1.5, 2.0, and $2.5 \mathrm{~ms}^{-1}$, respectively.

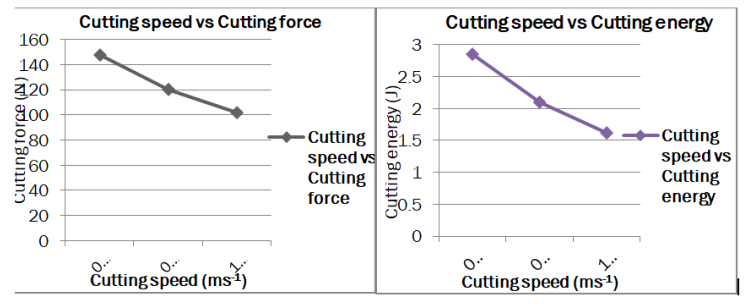

Figure 6. Effect of cutting speed on cutting force and cutting energy

$107|10-12| 4$ 
They concluded that the blade speed increases from 1.5 to $2.5 \mathrm{~ms}^{-1}$, decreasing the specific cutting energy by $77 \%$.

The analysis of variance for the effect of crop diameter, moisture content and cutter bar speed on cutting force is shown in Table 1 . The effect of crop diameter and cutting speed on cutting force had $1 \%$ significance and the moisture content on cutting force had $5 \%$ significance.

\section{CONCLUSION}

The effect of groundnut stem parameters on the required cutting force was recorded.The measured or obtained values of cutting force and cutting energy were used to develop the groundnut vine cutting machine.It was observed that stem diameter positively correlated, the moisture content and cutter bar speedshowed a negatively correlatedwith cutting force and cutting energy.It was concluded that maximum cutting force and cutting energy of $140-160 \mathrm{~N}$ and $2.5-3.0 \mathrm{~J}$, respectively to cut the groundnut crop stem.

\section{REFERENCES}

Azadbakht, M., AsI, A.R. and K.T. Zahedi. 2014. Energy Requirement for Cutting Corn Stalks (Single Cross 704 Var.). World Academy of Science, Engineering and Technology, Int. J.Bio.Biomolecular, Agric. Food and Biotech. Engi.,8 (5):479-482.

Allameh, A.and M.R. Alizade.2016. Specific cutting energy variations under different rice stem cultivars and blade parameters. IDESIA (Chile).,34 (5): 11-17.

Hoseinzadeh, B., Esehaghbeygi, A. and N. Raghami.2009. Effect of Moisture Content, Bevel Angle and Cutting Speed on Shearing Energy of Three Wheat Varieties. Wrld Appl. Sci. J.,7(9): 1120-1123.
Nisha, N. and M. Saravanakumar. 2019a. An Investigationon the effect of moisture content, crop diameter and cutting speed on cutting force of finger millet stem. Int.J.Agric. Sci. Res., 9 :187192.

Nisha, N. and M. Saravanakumar. 2019b. Development of Reciprocating Cutter Bar Test Rig for Measurement of Cutting Force of Finger Millets. Int.J.Curr. Microbiol.App.Sci.,8(04): 2441-2447.

Prasanthkumar, K. and M. Saravanakumar. 2020. Cassava Stem Crop Parameters Effect on Cutting Energy Adv. Res., 21(2): 25-30.

Ramachandran, S. and D. Asokan. 2020. Effect of Crop and Machine Parameters on Cutting Energy for Harvesting of Bengal gram crop. Int. J. Agric. Sci. Res., 10: 1-8.

Shahbazi, F. andM.N. Galedar.2012. Bending and Shearing Properties of Safflower Stalk. J. Agric. Sci. Tech., 14: 743-754.

Sushilendra.,Veerangouda, M.,Anantachar, M.Prakash, K.V. Desai,B.K. and S.N. Vasudevan. 2016. Effect of Blade Type, Cutting Velocity and Stalk Cross Sectional Area of Chickpea Stalks on Cutting Energy, Cutting Force and Specific Energy. Int. J. Agric. Sci., 8:2658- 2662.

Thulasiram, R., Alagumani,T., Raman, M.S. andG. Parthasarathi. 2018.Resource-Use Efficiency of Groundnut Cultivation in Tamil Nadu. Int.J.Curr. Microbiol.App.Sci.6: 351-357

Talpur, M.A., Changying, J.,Chandio, F. A. Junejo, S. A. and I. A.Mari.2011. Application of oven drying method on moisture content of ungrounded and grounded (long and short) rice for storage. J. Stored Prdts and Postharvest Res.2(12).,245 - 247.

https://pjtsau.edu.in/files/AgriMkt/2019/ OI_Groundnut_March_2019.pdfSource: www. agriwatch.com 